Handbook of Technical Instruction for Wireless Telegraphists

By H. M. Dowsett and L. E. Q. Walker. Seventh edition, extensively revised and enlarged. Pp. xx+664. (London: Iliffe and Sons, Ltd., 1942.) 25s. net.

$T^{N}$ such a rapidly growing subject as radio comImunication, a technical book which has survived to a seventh edition must first have possessed a very sound basis in its original form, and secondly it must have been very wisely kept abreast of the subject by its authors. All wireless operators of the pre-1914 vintage will remember the first edition by J. C. Hawkhead; this book was a standard work of its time for all would-be operators studying to qualify for the Postmaster-General's certificate. The latest edition maintains the traditions of its forerunners in providing for operators and engineers a complete course of instruction in the general principles and practice of marine wireless communication.

The work has been brought as fully up to date as is possible in a field that is not infrequently disturbed by novel applications of a somewhat revolutionary nature. It deals with the whole range of a ship's communication equipment from the power supply to the transmitting aerial, and from the crystal detector or valve receiver in a small ship to the elaborate loudspeaker installation and public address system in a luxury liner. The technical treatment also covers such aids to navigation as direction finding, depth sounding and distress call apparatus. One of the main features of the book is the large amount of photographic and circuit diagrammatic material given on all types of commercial radio-marine equipment in use at the present time. In view of the somewhat long life possessed by some of this equipment, the authors appear to have overcome successfully the difficult task of replacing obsolete material by deseriptions of current designs, without making the resulting book unduly large.

The volume may be thoroughly recommended to all who are concerned with marine radio communication, not only to assist them to pass their qualifying examinations, but also as a work of reference during their active careers.

\section{A Check-List of British Birds}

With a Short Account of the Status of Each. Revised edition. Compiled from "The Handbook of British Birds". By H. F. Witherby. Pp. 78 . (London : H. F. and G. Witherby, Ltd., 194I.) 5s. net.

A $S$ a companion to the "Handbook of British $A$ Birds" (five volumes), the small but valuable "Check-List of British Birds" has just recently been prepared by Mr. H. F. Witherby. This list of British birds is reprinted from the "Handbook": it is set down in the briefest possible form; for fuller particulars the "Handbook" itself must be consulted. No fewer than 424 species of birds have been admitted to the British list ; of these, 219 species have bred in Britain during the present century.

The "Check-List" is clearly printed, on excellent paper, and will prove a valuable addition to the list of ornithological publications.

On p. 42 is a printer's error which may perhaps be altered in a future edition. Here it is stated that the osprey last bred in Scotland in 1902. For 1902, the year 1908 should be substituted. The last accepted nesting of the osprey in Scotland (although there is a possibility that the species has bred later) was in the year 1908, on Loch Arkaig in Invernessshire. Cameron of Lochiel, on whose property these ospreys nested, writes to me as follows: "The Ospreys nested on Loch Arkaig in 1908. One solitary bird returned for five years afterwards, and was last seen in 1913. I believe this bird was shot in Ireland, as I myself saw a stuffed osprey in the south of Ireland, and was told that the bird had been shot in 1913. In 1907 there were three young birds in the Loch Arkaig eyrie. In 1908 the eggs were stolen."

Ospreys still visit the Highlands of Scotland on migration, and it is possible that one year a pair will remain to nest in some tree or ancient castle of an ancestral loch.

Seton Gordon.

\section{Short Wave Wireless Communication}

Including Ultra-Short Waves. By A. W. Ladner and C. R. Stoner. Fourth edition, revised and enlarged. Pp. xv +573. (London: Chapman and Hall, Ltd., 1942.) 35s. net.

$T$

HIS now well-known technical book was first published about ten years ago, and the fact that a fourth edition has become necessary shows that its popularity is being well maintained among the constantly increasing number of radio communication engineers and physicists. A notice of the third edition appeared in NATURE of November 14, 1936, and it is noted with some satisfaction that the opportunity has now been taken to re-arrange the chapters in a more suitable manner.

In so far as the censor will permit, the whole work has been revised and brought up to date to form a comprehensive treatise on the technical principles and application of radio telegraphic and telephonic communication on wave-lengths less than about 100 metres. A chapter entitled "Electron Oscillators" contains much new material on the various types of oscillators available for the ultra-short wave-lengths less than 10 metres. A new chapter deals with highfrequency therapeutic apparatus, and attempts to present in a clear manner the facts, as well as the very controversial claims, covering the application of high-frequency radio apparatus to medical treatment.

This new edition of the book deserves to have continued success.

Brompton Hospital Reports

A Collection of Papers recently Published from the Hospital. Vol. 10, 1941. Pp. vii $+127+29$ plates. (London: Brompton Hospital, 1942.) 5s. net. $W^{\text {ITH the exception of a paper on the "Per- }}$ sistence of Lipiodol in the Lungs after Bronchography" all the articles in these reports, of which Dr. Maurice Davidson has succeeded the late Dr. Bosanquet as editor, have previously been published in various medical periodicals. Three of the ten articles are of special interest at the present time, as they are devoted to chest surgery in war, while the rest deal with the etiology of subacute pulmonary infections and erythema nodosum, the medical aspects of chronic empyema and tumours of the lungs. An authors' index to the first ten volumes, a subject index to the first nine volumes, and a subject index to the present volume are appended. 